\title{
A case of near-drowning: are safety standards in sports adequate?
}

\author{
Manouri P Senanayake ${ }^{1}$, R Ajanthan1, P Aluthge ${ }^{2}$
}

Sri Lanka Journal of Child Health, 2002; 31: 66-8

(Key words: Near drowning)

\section{Introduction}

Childhood is the ideal time for encouragement of sports because physical activity levels and patterns, once established, last into adult life ${ }^{1,2}$. Injuries will occur but are often minor and do not warrant hospital admission.

Sports-related injuries account for over 3\% of the workload of a paediatric accident and emergency department in the United Kingdom ${ }^{3}$. In the absence of a reporting system or surveillance in Sri Lanka, the epidemiology of childhood sporting injuries and the circumstances of their occurrence remain unknown.

We report a life-threatening sports-related incident in a school boy.

\section{Case report}

A 15 year old school boy experienced a neardrowning episode in the Beira Lake during rowing practice. He and his crew belonged to 'the team' of a leading Colombo school with membership in a premier rowing club in the city. At a distance of over one kilometre from the coach, their boat capsized, when oarsmen attempted switching of oars of same side, a procedure neither recommended nor permitted. Our patient did not know how to swim. (Ability to swim is not a prerequisite for rowing in this school, nor are life jackets).

His feet were fastened to 'stretcher' by an improvised method since the strappings in his boat were broken. Therefore he failed in his attempts to release himself when underwater and remained trapped under the capsized boat. He was rescued by workmen of a nearby construction site. First-aid was given by those present.

On arrival in hospital, his oxygen saturation (by pulse oximetry) was $65 \%$ in air. Chest x-ray, one hour after rescue, showed severe pulmonary oedema (Figure 1). Arterial blood gas analysis while being ventilated with $100 \%$ oxygen showed - pH 7.33, pO2 $91 \mathrm{~mm} \mathrm{Hg}$, pCO2 $38.8 \mathrm{~mm} \mathrm{Hg}$ and base excess (-)4.9. He was intubated and ventilated with intermittent positive pressure for 2 days.

\footnotetext{
${ }^{1}$ Senior Lecturer in Paediatrics, University of Colombo ${ }^{2}$ Consultant Anaesthetist, National Hospital of Sri Lanka.
}

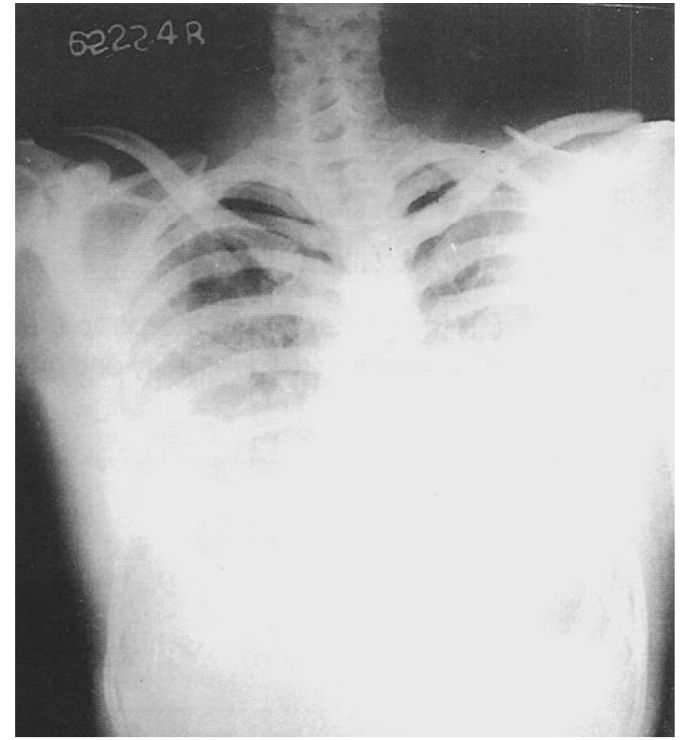

Figure1. Pulmonary oedema one hour after rescue.

Serum sodium was $134 \mathrm{mEq} / 1$ and serum potassium $4.3 \mathrm{mEq} / 1$. Klebsiella species (pure growth) was isolated on sputum culture. An aspiration pneumonia of the right lung (Fig. 2) was treated with intravenous Co-amoxiclav and chest physiotherapy.

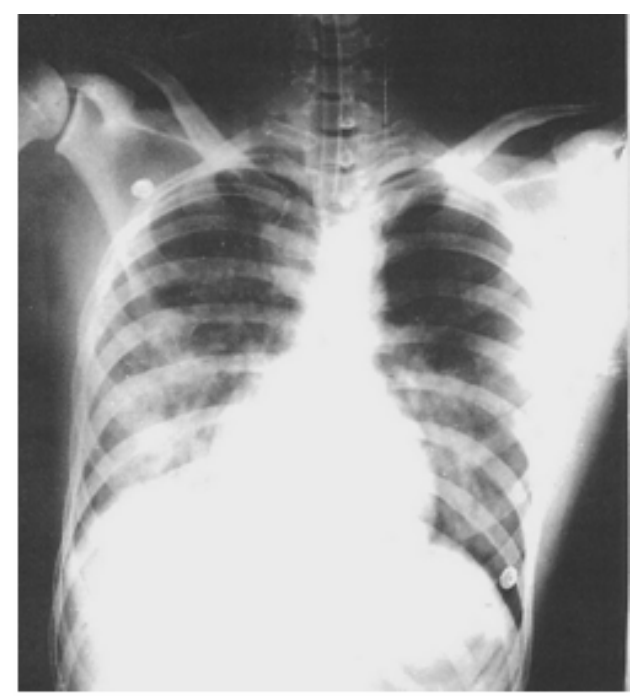

Figure 2 Aspiration pneumonia of right lower zone. 
On Day 3, eight hours after weaning off the ventilator, he became oxygen dependent again and required oxygen at $3-4 \mathrm{l} / \mathrm{min}$ for 8 days following complete radiological resolution.

Prior to full recovery a corneal injury to left eye and a depressed mood needed attention.

\section{Discussion}

The pulmonary effects our patient developed illustrate the pathophysiology of near drowning.

\section{Sequence of events in drowning / near-drowning}

As a result of prolonged submersion, the diving reflex and voluntary breath holding (caused by impact with water and initial panic) are lost when hypercarbic and hypoxic drives bring about a breaking point in these protective mechanisms. Thereafter, relaxation of laryngeal spasm and submerged breaths (or gasps) occur, resulting in inhalation and passive entry of water into the lungs.

\section{Non cardiogenic pulmonary oedema}

The rapid occurrence of severe pulmonary oedema, that we saw in our patient, was a result of intense inflammatory reaction and capillary leak caused by damage to alveolar pneumocytes. This may have been chemically mediated, since the water he was submerged in, was highly polluted. Intubation and ventilation corrected this secondary (non cardiac) pulmonary oedema.

\section{Bacterial pneumonia}

An aspiration pneumonia (due to Klebsiella infection) set in. The water from near the site of the accident was, on testing, faecally contaminated and chemically polluted.

\section{Primary alveolar dysfunction ("secondary drowning")}

Chemical or bacterial pneumonitis did not cause primary alveolar dysfunction, a condition that sometimes occurs 3 to $72 \mathrm{hrs}$ after initial recovery. This is a serious complication needing reintubation and ventilation

\section{Ventilation perfusion mismatch}

The increased oxygen requirement that manifested, even when our patient was otherwise well, was probably due to ventilation perfusion mismatch, a recognized complication of near-drowning. Fresh water denatures (and salt water dilutes) surfactant. The non-functional surfactant causes intrapulmonary shunting resulting in a ventilation perfusion mismatch which may take days to return to normal.

\section{Fluid or electrolyte disturbances}

This did not occur in our patient. Hypervolaemia, haemodilution and hyponatremia of fresh water drowning and haemolysis and hyperkalemia of salt water drowning are rarely encountered because the large volumes $(22 \mathrm{ml} / \mathrm{kg})$ necessary for such fluid shift, do not enter the lungs. These changes are demonstrated in animal models in laboratories.

This case report demonstrates issues of safety, supervision and discipline in sports. Supervision by an adult - teacher, coach or referee, is mandatory in sports activities of school children. So is discipline. We found a dangerously low level of safety in a situation where precautions are vital, and resources are expected to be comparatively good. A population-based study of childhood sports injuries in Sri Lanka would help provide guidelines for advocacy and awareness on safety standards in sports in children 4 .

\section{Acknowledgements}

We thank Dr. S. D. Athukorale consultant microbiologist, National Hospital of Sri Lanka; medical and nursing staff of the Intensive Care Unit of Accident Service, National Hospital of Sri Lanka and Durdans Hospital Colombo for assistance in caring for this patient.

\section{References}

1. Armstrong N, Balding J, Gentle P, Kirby B. Patterns of physical activity among 11 to 16 year old British children. British Medical Journal 1990; 301: 203-5.

2. Gloag D. Exercise, fitness and health: people need to be more active more often. British Medical Journal 1992; 305: 377-8.

3. Smith B H, Beattie T F. Sports injuries in children. Paediatrics Today 1993; 1: 12-3.

4. De Loes M, Jacobsson B, Goldie I. Risk exposure and incidence of injuries in school physical education at different activity levels. Canadian Journal of Sports Science 1990; 15 (2): 131-6. 